\title{
Varieties of capital and gender party office in Italy
}

\author{
Paola Bordandini and Rosa Mulè* \\ Department of Political and Social Sciences, Bologna University, Italy
}

(Received 22 December 2019; final version accepted 29 December 2020)

\begin{abstract}
This article advances a new approach based on 'varieties of capital' to explain gendered upward mobility in political parties. Research on gender political advancement unduly neglects women delegates to national party congresses. Our work seeks to redress the imbalance by drawing on data gathered from 5,122 questionnaires issued to national party delegates at 20 national conventions that took place between 2004 and 2013 in Italy. To analyse the data we develop a new framework based on 'varieties of capital'. Our approach builds on Bourdieu's three types of personal capital - economic, social and cultural - and interprets the findings borrowing analytical tools from recent feminist institutional theory, especially the concept of homosocial capital. Comparisons of male and female party delegates in terms of background and their political trajectories reveal the persistence of an uneven playing field, with gendered hierarchies in Italian political parties confirming an international pattern.
\end{abstract}

Keywords: gender; party office; varieties of capital; national party delegates; informal institutions..

\section{Introduction}

In Italy, concern for gender political advancement has recently been addressed by a small but growing literature (Belluati, Piccio and Sampugnaro 2020; Guadagnini 2005; Palici di Suni 2012; Pansardi and Vercesi 2017; Papavero and Zucchini 2018). This literature investigates gender legislative behaviour as well as gender equality in Italian parliamentary representation. However, gender ascendant career within party organisations in Italy has somehow been neglected, creating a situation in which we have a gap in our knowledge about career paths.

This is regrettable, since modern party organisations are undergoing dramatic changes. Their structure has become more hierarchical and connected to elites in allied professions ("cadre parties') (Bardi, Bartolini and Trechsel 2014). While party resources are becoming more and more concentrated at the top, party membership is increasingly multi-faceted, multi-speed and requires multi-stream activation (Achury et al. 2020; Power and Dommett 2020). The increasing concentration of power at the top may adversely affect women's opportunity structure in light of the traditional female under-representation in the party's upper echelons.

Political parties are still the central mechanism by which the democratic processes of delegation and accountability work in practice (Müller 2000, 309), so that party change raises issues regarding gender representation and the quality of democracy.

\footnotetext{
*Email: rosa.mule@unibo.it
}

(C) The Author(s), 2021. Published by Cambridge University Press on behalf of the Association for the Study of Modern Italy. This is an Open Access article, distributed under the terms of the Creative Commons Attribution licence (http://creativecommons.org/licenses/by/4.0/), which permits unrestricted re-use, distribution, and reproduction in any medium, provided the original work is properly cited. 
In general, the political science literature shows that gender gaps are ubiquitous. These gaps have somewhat reduced in industrialised countries over the past 30 years, with an increasing number of women being elected as party leaders and members of parliament (Celis, Krook and Meier 2011; Dahlerup and Leyenaar 2013). Yet gender inequalities in the political sphere remain. Whether women are less likely to seek elected office or whether it is the dearth of women in the pipeline to power (Homsen and King 2020), women are still far from matching men's level of involvement in political actions, influence and representation.

Scholars of party organisation have convincingly argued that party office is a key political resource (Kopecky and Mair 2012). The party echelons have more chances of allocating resources for patronage and controlling future appointments and careers. We know from extant literature that holding party office increases an individual's chance of being appointed to legislative, ministerial and post-ministerial positions (Verge and Claveria 2017). Indeed, party service is a 'brokerage job' that typically predates selection as a candidate (Evans 2012).

Against this background, it is surprising that there is little research on female party delegates. A recent exception is a field experiment centred on women delegates at subnational level in the United States (Karpowitz, Monson and Preece 2017), but women delegates to national party congresses have been unduly neglected. In this article we explore party office-holding by examining the political resources of Italian male and female party delegates to national party congresses. The article builds on Bourdieu's power resource typology based on three types of personal capital, namely economic, social, cultural. It then expands this approach with recent advances in institutional feminist theory, stressing informal mechanisms that may affect the gender-neutrality of personal capital (Bjarnegård and Kenny 2015; Luhiste 2015). The aim of this article is exploratory and descriptive. Our central question is whether there are similarities or differences in the gender distribution of personal capital and what mechanisms may account for the distributions observed. This question deals with a very crucial topic of female representation and participation in politics, but has remained unanswered in Italian studies concerned with gender political representation.

Our findings draw on a unique dataset on Italian national party delegates that spans about a decade from 2004 to 2013. To the best of our knowledge, this is the only recent dataset to focus on national delegates of 20 different parties for an approximately ten-year period. This dataset is used in a number of publications on Italian politics, but gender careers in party organisations have somehow been overlooked (Bordandini 2013; Bordandini and Mulè 2018; Ignazi and Bordandini 2018). We compare the demographic profiles and political trajectories of male and female delegates to national party congresses between 2004 and 2013 in Italy. The demographic differences concern education, profession and family education. There are striking differences in political career paths. Both men and women have considerable political experience, but men are far more likely to have held executive positions in party organisations and social associations that provide politicians with access to institutional resources.

The article is divided into four sections. The next section maps the theoretical framework of 'varieties of capital'. The second describes the dataset, the unit of analysis and case selection. The third explores the gender distribution of personal capital and points to interpersonal homosocial capital as a mediating dimension with gender consequences. The final section summarises our results.

\section{Theoretical framework: varieties of capital}

Research concerned with careers in party organisations has recently applied Pierre Bourdieu's work to shed light on internal power dynamics (Davis 2010; Kauppi 2003; Wacquant 2004). In 
Bourdieu's view, social actors have different endowments of economic, social and cultural capital that determine their position. For Bourdieu, the most significant types of personal capital to acquire are 'economic', 'cultural' and 'social'. In his work the meaning of economic capital is straightforward - it simply means money. Economic capital offers several advantages, including access to more exclusive forms of occupation. Cultural capital is more complex. It accumulates through a mix of formal and informal education. Education provides the cognitive skills necessary for acquiring, mastering and controlling information vital for evaluating executive and policy options. Social capital is different. It depends on skill in establishing relations with others in social networks. ${ }^{1}$ These are 'more or less institutionalised relationships of mutual acquaintance and recognition' (Bourdieu 1986, 21). By exploring the distribution of Bourdieu's personal capitals, scholars reach conclusions regarding power positions of party activists and leaders. Though innovative and interesting, this research neglects gender upward mobility within political parties.

To explore the gender distribution of party office, we follow the lead of a number of authors who argue for positive engagement between Bourdieu's social theory and gender studies (Krais 2006; McCall 1992; Reddy, Sharma and Jha 2019). In Bourdieu's framework, gender is not an analytical category or personal capital (Huppatz and Goodwin 2013); gender is considered a 'secondary' constituent of social divisions. It is therefore liable to the criticism that this 'secondary dimension' reproduces simplistic sexist dichotomies of male domination and female subordination (McLeod 2005). McCall (1992), however, warns against a superficial reading of Bourdieu's social theory. She clarifies that Bourdieu "variously refers to secondary criteria as "hidden", "unofficial", and "real"'. She explains that a 'secondary criterion', though 'unofficial', is pervasive in social space. In this way Bourdieu exposes how real principles of selection and exclusion are hidden, justifying the usefulness of this analysis to gender studies (McCall 1992, 24). In Bourdieu's social theory, 'secondary' refers to a mediating dimension of position, but then he fails to capture the logical extension of this dimension in political advancement (McCall 1992, 842).

A focus on this mediating dimension is central to recent work on the gender dynamics of political recruitment (Bjarnegård and Kenny 2017; Piscopo and Kenny 2020; Waylen 2017). This new wave of research offers a nuanced understanding of how gender shapes upward mobility by shedding light on informal institutions and hidden practices. Waylen's edited collection (2017) addresses informal norms and codes that sustain gender bias and discrimination, indicating that removing formal obstacles to gender political advancement is insufficient. These works tackle the conceptual and methodological challenge of examining the intangible and implicit yet resilient and tenacious nature of informal institutions. They disentangle informal and informality rules to examine gender inequalities in executive bodies (Francheschet 2017). They suggest that the dynamics of gendered power inequalities are ingrained in many dimensions of political institutions, from party office to ministerial appointments, and cut across different political systems.

Most notably, these scholars shift the research agenda away from explaining gender gaps in ambition, resources and motivation towards understanding the informal institutions that reinforce male dominance. They argue for an 'informal' turn in institutional analysis that addresses the discriminatory effect of gendered norms which pervade the candidate selection process (Bjarnegård and Kenny 2017, 203). These authors propose a new research agenda for the field of 'gender and political recruitment' centred on informal institutions.

Though early feminist work acknowledged the importance of formal and informal institutions, nevertheless the dominant framework to explore party recruitment has been the supply and demand metaphor developed by Norris and Lovenduski (1995). This first generation of research emphasised obstacles to the recruitment of women at individual level, including resources, motivation and ambition that create a bias against women (Fox and Lawless 2011). 
Doubts about this emphasis on supply-side factors in accounting for women descriptive underrepresentation are raised by the second generation of researchers. Evidence suggests that individual characteristics, such as political ambition, cannot be explained by the psychological traits of the candidate (Allen and Cutts 2020). Women don't 'lean in' like men, not because of their lack of ambition or motivation or resources; rather, female under-representation stems from lack of demand by party gatekeepers (Kittilson 2013). Demand-side factors involve the political elites' concept of the 'ideal candidate'. For example, Niven (1998) finds that party elites describe the 'ideal candidate' with stereotypical masculine characteristics.

However, Krook (2010b) contends that the metaphor of supply and demand cannot explain the pervasiveness of female under-representation in political recruitment in every country of the world. Stalled progress in explaining gender political recruitment is not the result of a lopsided focus on one set of sources and therefore cannot readily be improved simply by theorising 'the other side'. Since there are more women in the world than men, what accounts for the distortion of female under-representation? Supply and demand dynamics do not operate in a vacuum but unfold within political institutions where formal and informal rules and procedures may generate distortions in political recruitment.

Building on the work that has been done using the supply and demand framework, the third generation of feminist scholars moves beyond this approach to focus on mechanisms that interact with individual supply and demand resources. It does so by combining gender as an analytical category with the insights of institutionalism, exploring the potential gender distortions rooted in formal and informal institutions.

Many factors justify an emphasis on institutions. Institutions are weapons of coercion and redistribution but they also help mitigate problems of collective action; institutions resist redesign, ultimately because they incorporate a vested interest in their standard operating procedures. The term institution is used to refer to informal codes of behaviour, written contracts or complex organisations (Lowndes 1996). Institutions are associated with conventions and customs embedded in the organisational structure that provide frames of meaning guiding human action. Since actions are inserted in institutional structures of norms, expectations and traditions (Marche and Olsen 1989, 23), institutions should not be left out of any serious analysis of gender political recruitment.

For this reason, feminist institutional theory moves beyond the supply and demand metaphor. It is not just a question of supply and demand: matters may be more complex. For instance, formal and informal mechanisms may reinforce the power of dominant players in politics, traditionally men (Cheng and Tavits 2011). Josefsson (2020) finds that male party leaders believe women are less trustworthy and loyal than men, which makes them feel threatened by female candidates. Thus, political recruitment is gendered because the constructions of masculinity and femininity are intertwined in the 'logic' of the recruitment process, shaping 'ways of valuing things' (Bjarnegård and Kenny 2017, 209).

By the same token, O'Brien (2015) demonstrates that female candidates play by a different set of rules than their male counterparts. For example, male leaders can be praised for appointing women to their cabinets, while female leaders appointing 'too many' female ministers may not be interpreted as progressive, but rather accused of favouritism or identity politics (O'Brien et al. 2015). Along the same line, Müller-Rommel and Vercesi (2017) explore gender differences in the paths to prime ministerial posts. They find that female prime ministers have more political experience in both parliament and cabinet than their male counterparts, but a shorter duration in office once they become prime minister, indicating that their political resources are less valued than men's.

This discussion is lively and useful because it goes to the heart of key theoretical and empirical questions concerned with gender political recruitment: Is there a gender logic in political 
recruitment? Are institutions gender-neutral? Gender-neutral formal selection criteria may also have unintended gendered consequences. Bjarnegård and Zetterberg (2019) carry out a cross-party comparative analysis that demonstrates how selection criteria may have 'unintended gendered consequences of seemingly gender-neutral formal selection criteria on the representation of men and women' (p. 325). This third generation of research on gender political recruitment examines the informal 'gendered institutional logic'. 'Gender is understood here as a conservative element of social relations based on perceived (socially constructed and culturally variable) differences between women and men, and primary ways of signifying (and naturalising) relationships of power and hierarchy' (Bjarnegård and Kenny 2017, 209). Gendered institutional logic interacts with individual supply and demand resources with potentially significant gender effects.

This new wave of research points to male homosocial capital as an important informal mechanism that helps understand the complex gender institutional logic of political recruitment (Verge and Claveria 2017; Bjarnegård 2013). Bjarnegård (2013) initially developed the concept of homosocial capital to shed light on political advancement in party organisations. Borrowing from the literature on recruitment processes in other organisations, Bjarnegård defines homosocial capital as an 'uncertainty reduction resource' in an otherwise unpredictable political environment. She argues that similarity between individuals in terms of perceived characteristics is seen to ensure predictable behaviour and, in the long run, generate trust. In Bjarnegård's approach, homosocial capital has two main components: a perceived pragmatic necessity to build links with those having access to important resources, and a more psychological desire to cooperate with individuals whose behaviour can be understood, predicted and trusted. Thus, homosocial capital is an interpersonal mechanism that interacts with individual supply and demand dynamics.

Building on this new wave of feminist institutionalism, we argue that Bourdieu's social theory of personal capital and his emphasis on the 'hidden' nature of principles of candidate selection dovetail with the recent feminist-institutional focus on the interpersonal quality of homosocial capital. This cross-fertilisation may enliven the debate because one camp can fruitfully borrow insights from the other to engage in a deeper treatment of gender political advancement. Granted, this article cannot do justice to the complexities of Bourdieu's social theory nor to those of feminist institutional theory. We limit our analysis to assessing whether differential endowment of personal capitals sustains individual career paths and whether the interpersonal homosocial capital may help understand any distorted outcome.

\section{Unit of analysis, case selection and data}

\section{Unit of analysis}

National party delegates are not just simply party members, but activists with long political militancy. They are pivotal members of the party communities thanks to organisational positions in politics and local associations. This is why they are known as 'middle level elite' (Reif, Cayrol and Niedermayer 1980; Niedermayer 1986). In most West European parties, delegates have traditionally been perceived as the privileged pool from which party leaders and candidates are selected (Baras et al 2015; Bordandini, Di Virgilio and Mulè 2011). Delegates act as a participatory linkage in party organisational chains because they build bridges between the rank-and-file and the upper echelons (Bordandini 2013; Rohrscheneier 1994).

This participatory linkage of party delegates between the 'party on the ground' and the 'party in the central office' is especially important today with the advent of new forms of party affiliation, such as multi-speed membership (Achury et al. 2020; Baras et al. 2015; Gomez et al. 2019; Hooghe and Kölln 2020; Kölln 2016; Scarrow 2015). New forms of party membership make 
responsiveness by national party delegates all the more important. In the motions submitted at party congresses, these delegates use responsiveness both as a means of appeasement of party activists and to reward valuable intra-party groups (Kaltenegger, Heugl and Müller 2019). Their speeches at party national congresses provide useful information about the relative location of actors' preferences (Greene and Haber 2016). As part of an internal representative and deliberative process, national party delegates articulate different viewpoints over the party's electoral strategy and policy programmes. The party congress is therefore a deliberative body where factional deliberation is filtered through leader mediation and conciliation. Ultimately, party congresses serve as venues for decision-making, shaping policy statements and party manifestos (Ceron and Greene 2019).

In such circumstances, the under-representation of women at national party congresses affects party policies, programmes and priorities. In her book The Politics of Presence, Anne Phillips (1995) argues that different life experiences and personal characteristics of representatives influence their viewpoints and policy priorities. Moreover, the representation of women at national party congresses is important because being nominated or elected a delegate is often the steppingstone to professional politics.

\section{Case selection}

In Italy a long line of scholarship addresses the key role of party activists and middle-level elites in promoting and preserving the quality of democracy (Cotta and Verzichelli 2000; Morlino 1991). Historically the two most powerful parties, the Christian Democratic Party and the Communist Party, enjoyed large membership and active middle-level elites. As in most west European democracies, high degrees of party institutionalisation helped these parties exert strong control on society and on the operation of institutions.

In the last ten years many western European democracies have experienced sequences of party system deinstitutionalisation, with the gradual weakening of the stability and predictability of interparty competition within a given country. Italy is an interesting case study because the process of party deinstitutionalisation was sudden and more dramatic. In the early 1990s, the 'Tangentopoli' inquiry marked a sharp turn in Italian politics, propelling the implosion of traditional party organisations. The advent of new parties, the fruit of a sequence of extinctions, new entries, splits and mergers, began in 1993-4 and continued for about 20 years (Bartolini, Chiaramonte and D'Alimonte 2004; Calise 2010; Cotta and Verzichelli 2000; Di Virgilio 2010; Ignazi, Bardi and Massari 2010; Pasquino 2002). This political upheaval set in motion a relentless process of party deinstitutionalisation that is still underway, with unpredictable consequences for electoral outcomes (Chiaramonte and Emanuele 2015).

Moreover, Italy is an interesting case insofar as it is a highly gendered society that reflects the persistence of traditional norms of gender-appropriate behaviour (Sartori, Tuorto and Ghigi 2017). More generally, in parliamentary systems such as Italy, holding party office may be more relevant for candidate selection because ministers typically have broad political party backgrounds (Siaroff 2000). Finally, the availability of a unique dataset on national party delegates spanning about ten years reinforces the meaningfulness of the Italian case.

\section{Data}

Although not on an ongoing basis, party delegates have been a tested research subject in the literature on political parties. The first comparative research based on this unit of analysis dates back to the 
1970s, namely, the EPPMLE Project (European Political Parties Middle Level Elites). The project involved 12 European countries (Belgium, Denmark, Germany, Spain, France, Ireland, Northern Ireland, Italy, Luxembourg, the Netherlands, Portugal and the United Kingdom) and 68 parties; surveys on party delegates were conducted between 1978 and 1981, mainly with the same research design. The EPPMLE investigation marked a milestone in comparative middle-level party elite research, but unfortunately there has not been a comparative follow-up. Case studies on party delegates are still conducted in single countries, such as France, Italy, Spain, Portugal and Germany, but the datasets have not been harmonised for comparative analyses (Baras et al. 2015; Lisi 2015).

Our dataset is based on the Italian delegates research project, an inter-university research programme co-funded by the Ministry of Education, University, and Research and four universities (Florence, Bologna, Cosenza and Trieste). ${ }^{2}$ Data was collected by means of a structured selfadministered questionnaire distributed during national party congresses (except for the Verdi [Green] party, for which a postal survey was organised immediately after their national congress). The questionnaire consisted of two parts - a general section for all parties and a second, specific section for party characteristics and the political context in which their congress took place. The questionnaire was distributed to all delegates to the national party congress.

Table 1 illustrates the distribution of delegates to the national party congress by party and gender. ${ }^{3}$ It shows that 5,122 delegates returned the questionnaire, and that the percentage of respondents varied between a maximum of $48.5 \%$ and a minimum of $8 \%$. The share of women respondents was fairly similar to the share of women in the party delegate universe ( 9 out of 20 political parties provided no information on the total number of their delegates). Interestingly, 59 delegates did not reply to the question regarding their gender.

The data indicate that irrespective of party ideology, there was about one woman to every two male delegates; women delegates are on average $48 \%$ fewer than men. As expected, the data revealed higher woman quotas in left-wing parties, which is consistent with the literature that detects more gender 'friendliness' in left-wing parties (Ewig and Marx 2013; Lovenduski and Norris 1993). ${ }^{4}$

The parties involved in the surveys differed in size, electoral appeal and geographical distribution of votes. In most cases, delegates were elected by party members, directly or indirectly, except for the Radicals, where any party member can attend the national congress becoming a de facto delegate.

\section{The gender distribution of personal capital}

This section traces the distribution of personal capital between male and female party delegates. Broadly speaking, the step from concept to variable is always challenging and liable to criticism, while empirical analysis is often limited by the availability of data. Our study is no exception. Here we followed mainstream operationalisation of personal capital. Economic capital was measured by taking the delegate's profession and productive sector as proxies. These indicators are only apparently gender-neutral, as horizontal and vertical gender segregation affect labour markets in every country.

Cultural capital was operationalised with the variable 'education' of the party delegate and her/ his father (unfortunately no information was gathered for 'mother's education'). Our data did not allow us to differentiate the fields of delegates' qualifications (medicine, engineering, arts etc.) but only the level of education (primary, secondary, university).

Social capital was operationalised with the variable 'membership of social groups and social organisations' and 'position in associations'. These indicators are appropriate because social networks are extremely useful in political recruitment and mobility (Bourdieu 1986). Joining associations fosters social capital because it strengthens social networks. 
Table 1. Gender distribution of national party delegates by party (2004-2013)

\begin{tabular}{|c|c|c|c|c|c|c|c|}
\hline \multirow{2}{*}{$\begin{array}{l}\text { Political } \\
\text { family }\end{array}$} & \multirow{2}{*}{$\begin{array}{l}\text { National } \\
\text { Party } \\
\text { Congress }\end{array}$} & \multicolumn{2}{|c|}{$\begin{array}{l}\text { National party } \\
\text { delegates SAMPLE }\end{array}$} & \multirow{2}{*}{$\begin{array}{c}\Delta \% \\
\text { Women-men }\end{array}$} & \multirow{2}{*}{$\begin{array}{l}\text { Respondents by } \\
\text { party }\end{array}$} & \multirow{2}{*}{$\begin{array}{l}\text { Sample coverage (\% of } \\
\text { respondents on total } \\
\text { population) }\end{array}$} & \multirow{2}{*}{$\begin{array}{l}\% \text { of women delegates attending } \\
\text { the party congress (population } \\
\text { of women delegates) }\end{array}$} \\
\hline & & \% Male & $\%$ Female & & & & \\
\hline \multirow[t]{5}{*}{ Left } & FdS 2010 & 74.0 & 26.0 & -48.0 & 259 & 43 & $\mathrm{n} / \mathrm{a}$ \\
\hline & Prc 2005 & 78.2 & 21.8 & -56.4 & 208 & 30.1 & 25 \\
\hline & PdCi 2004 & 72.4 & 27.6 & -44.8 & 290 & 40.6 & 23 \\
\hline & Sel 2010 & 65.2 & 34.8 & -30.4 & 385 & 44 & 27 \\
\hline & Verdi 2006 & 80.0 & 20.0 & -60.0 & 131 & 23.1 & 26 \\
\hline \multirow[t]{9}{*}{ Centre-left } & \begin{tabular}{|l|} 
Ds 2005 \\
\end{tabular} & 63.3 & 36.7 & -26.6 & 434 & 27.5 & 38 \\
\hline & Radicali 2008 & 79.1 & 20.9 & -58.2 & 173 & 48.5 & 23 \\
\hline & Ds 2007 & 57.5 & 42.5 & -15.0 & 324 & 23.8 & 39 \\
\hline & Sdi 2004 & 80.6 & 19.4 & -61.2 & 352 & 44.5 & 25 \\
\hline & Pd 2013 & 51.4 & 48.6 & -2.8 & 352 & 35.2 & 50 \\
\hline & Pd 2009 & 51.7 & 48.3 & -3.4 & 205 & 20.6 & 50 \\
\hline & Dl 2007 & 78.4 & 21.6 & -56.8 & 305 & 16.5 & 14 \\
\hline & D1 2004 & 85.7 & 14.3 & -71.4 & 310 & 22.1 & $\mathrm{n} / \mathrm{a}$ \\
\hline & Npsi 2005 & 88.5 & 11.5 & -77.0 & 206 & 13.7 & $\mathrm{n} / \mathrm{a}$ \\
\hline \multirow[t]{2}{*}{ Centre } & Udeur 2005 & 89.5 & 10.5 & -79.0 & 96 & 8.0 & $\mathrm{n} / \mathrm{a}$ \\
\hline & Udc 2005 & 92.5 & 7.5 & -85.0 & 179 & 9.4 & $\mathrm{n} / \mathrm{a}$ \\
\hline \multirow[t]{2}{*}{$\begin{array}{l}\text { Centre- } \\
\text { right }\end{array}$} & \begin{tabular}{|c|} 
Forza Italia \\
2004 \\
\end{tabular} & 80.3 & 19.7 & -60.6 & 382 & 17.0 & $\mathrm{n} / \mathrm{a}$ \\
\hline & An 2009 & 90.1 & 9.9 & -80.2 & 143 & 9.5 & $\mathrm{n} / \mathrm{a}$ \\
\hline \multirow[t]{2}{*}{ Right } & \begin{tabular}{|c|} 
La destra \\
2008
\end{tabular} & 81.5 & 18.5 & -63.0 & 284 & 9.5 & $\mathrm{n} / \mathrm{a}$ \\
\hline & Msft 2004 & 90.3 & 9.7 & -80.6 & 104 & 20.8 & $\mathrm{n} / \mathrm{a}$ \\
\hline \multicolumn{2}{|l|}{ Total } & 73.9 & 26.1 & -47.8 & & & \\
\hline \multicolumn{2}{|l|}{$N$} & 3742 & 1321 & & $5122 *$ & & \\
\hline
\end{tabular}


Table 2. Gender distribution of economic capital. Profession and public/private employment by gender and age (percentages)

\begin{tabular}{|l|c|c|c|c|}
\hline \multirow{2}{*}{} & \multicolumn{2}{|c|}{ Italian national party delegates } & \multirow{2}{*}{ Tot-2013 } \\
\cline { 2 - 4 } & Women & Men & \multicolumn{1}{|c|}{$\Delta$ Women-men } & \\
\hline Profession & & & & \\
\hline Professional, managers and entrepreneurs & 28.5 & 37.1 & -8.6 & 34.9 \\
\hline & & & & \\
\hline Under 40s & 25.1 & 30.4 & -5.3 & \\
\hline Over 40s & 30.1 & 40.3 & -10.2 & \\
\hline & & & & \\
\hline Public/private sectors & & & & \\
\hline Private sector & 41.7 & 53.2 & -11.5 & \\
\hline Public sector & 58.3 & 46.8 & 11.5 & \\
\hline & & & & \\
\hline 40 years or under & 39.6 & 35.8 & 3.8 & \\
\hline Over 40s & 66 & 50.9 & 15.1 & \\
\hline
\end{tabular}

\section{Economic capital: profession}

Job status may well buttress upward mobility by developing skills, know-how and support networks. It affects the time delegates are able to devote to political activities to strengthen their social networks and political circuits. Our data captures major gender gaps in the quantity and quality of job position (Table 2). About 35\% of party delegates were employed in high status jobs, such as professions, management and entrepreneurship, yet there are remarkable gender differences. Women delegates holding executive positions are 8.6 percentage points behind men, though the gap narrows slightly in younger generations. This means that women control fewer economic resources than men. They consequently reach the intermediate level of party office with weaker spill-over from their job status. By contrast, women delegates employed in the public sector were 11.5 percentage points ahead of men, and again this figure drops in younger generations.

\section{Cultural capital: education}

Cultural capital is a scarce resource that equips individuals with knowledge, practical skills and a sense of 'the rules of the game' in the educational system. These attributes are recognised and rewarded by institutional gatekeepers and peers (Bourdieu and Passeron 1977). We operationalised cultural capital with the gender distribution of education in party delegates and their fathers (there was no data on mothers' education). Father's education is an indicator of a delegate's cultural background. As mentioned above, education provides the cognitive skills necessary for acquiring and mastering the flow of information required to evaluate executive and policy options.

Table 3 indicates that among national party delegates, women were more educated than men. The gender difference is 10.5 percentage points higher for women $(50.4 \%$ men against $60.9 \%$ 
Table 3. Gender distribution of cultural capital. Party delegates by gender and age (percentages)

\begin{tabular}{|l|c|c|c|c|}
\hline \multirow{2}{*}{} & \multicolumn{2}{|c|}{ Italian national party delegates } & \multirow{2}{*}{ Total } \\
\cline { 2 - 5 } & Women & Men & \multicolumn{1}{|c|}{$\Delta$ Women-men } & \\
\hline Education & & & & \\
\hline High school graduate or less & 39.1 & 49.6 & -10.5 & 46.8 \\
\hline University degree & 60.9 & 50.4 & 10.5 & 53.2 \\
\hline & & & & \\
\hline 40 years or under & 63.3 & 53 & 10.3 & \\
\hline Over 40s & 59.7 & 49 & 10.7 & \\
\hline & & & & \\
\hline Father's education & & & & \\
\hline No high school & 49.7 & 55.9 & -6.2 & 54.3 \\
\hline High school or university degree & 50.3 & 44.1 & 6.2 & 45.7 \\
\hline & & & & \\
\hline 40 or under (High school or university degree) & 60.5 & 61.6 & -1.1 & \\
\hline Over 40 (High school or university degree) & 45.1 & 35.2 & 9.9 & \\
\hline
\end{tabular}

women), with a similar gap in the younger generation. ${ }^{5}$ The figures show that women's cultural background was from families with higher levels of education than families of male delegates, as measured by the father's education. Family cultural gaps disappear in the younger generation, probably because expansion of higher education in the 1970s increased the number of graduates. All in all, these results suggest that in Italy, women reach an intermediate level of party office with higher levels of cultural capital than men.

\section{Social capital: participation in associations}

In Bourdieu's view, social capital is related to an individual's social networks. ${ }^{6}$ Personal social capital is what individuals gain from their position in organisational networks. It yields better knowledge, power and promotion within and between organisations. Importantly, for Bourdieu social capital is the most effective form of capital for facilitating upward mobility (Bourdieu 1986). Bourdieu's personal capitals are individual resources that help explain why a party activist advances to party delegate. We operationalised the delegate's social capital with 'participation in associations' and 'positions in associations'. Table 4 shows that women delegates participate more in secular volunteer associations than men (57.6\% against $45.3 \%$ ), and are more active in environmental groups (39.2\% against 33.8\%). The data does not show any significant differences in gender participation in cultural, religious and recreational associations.

We measured the gender participation gap by calculating a participation index based on the number of associations the delegate belonged to. The index ranges from 0 to 5: 0 if the delegate is not a member of any association and 5 if $\mathrm{s} / \mathrm{he}$ is a member of all the associations. A delegate is deemed active in social networks if s/he is a member of more than two associations (high participation $>2$ ), because 2 is the median value. The participation index in Table 4 shows that 
Table 4. Gender distribution of social capital (percentage of 'yes' answers)

\begin{tabular}{|c|c|c|c|c|}
\hline & \multicolumn{3}{|c|}{$\begin{array}{l}\text { Italian national party } \\
\text { delegates 2004- } 2013\end{array}$} & \multirow[b]{2}{*}{ Total } \\
\hline & Women & Men & $\begin{array}{c}\Delta \\
\text { Women-men }\end{array}$ & \\
\hline Cultural and recreational & 73.4 & 73.7 & -0.30 & 73.7 \\
\hline Labour and professional & 52.3 & 51.9 & 0.40 & 52 \\
\hline Secular volunteer & 57.6 & 45.3 & 12.30 & 48.5 \\
\hline Religious volunteer & 18.4 & 20.5 & -2.10 & 20 \\
\hline Environmental & 39.2 & 33.8 & 5.40 & 18.4 \\
\hline $\begin{array}{l}\text { Participation index in social networks (range } 0-5) \text { : \% high } \\
\text { participation }(>2)\end{array}$ & 36 & 33 & 3 & 33.9 \\
\hline Position in associations (manager or ex manager) & 52.5 & 59.5 & -7.0 & \\
\hline
\end{tabular}

women delegates have higher degrees of involvement (36\% against 33\%) irrespective of whether the association is professional, recreational, secular or religious. The figures indicate that women join the party middle-level elite endowed with more social capital than men, as measured by the participation index. This result is important because, as mentioned in section 2, social capital is the most effective form of capital in facilitating upward mobility (Bourdieu 1986).

Since women delegates are endowed with higher levels of social capital, we expect that they should hold at least as many, if not more, executive positions than men in social associations. However, Table 4 tells a different story: fewer women hold executive positions than men in associations $(52.5 \%$ against $59.5 \%)$, in spite of women's higher participation index.

Overall, our data reveal that fewer women hold executive positions than men (about 11 percentage points less), despite being endowed with more social and cultural capital (Table 5). The most important implication is that personal capital is valued differently in the ascending party careers of women and men. Hence personal capital is not gender neutral: women's resources are valued less than men's.

\section{Towards understanding party-office gender dynamics}

Our results on the distributions of personal capital suggest an uneven political playing field. They confirm the contention that the game is 'organised to serve the aspirations, abilities and opportunities of elite men' (Piscopo and Kenny 2020, 6). They tally with Bourdieu's conception of gender as a 'hidden', unofficial criterion, a mediating dimension that interacts with individual resources and is pervasive in social space.

To help understand the dynamics of uneven playing fields, we borrow from recent advances in feminist institutional theory that point to a key informal mechanism: homosocial capital. One can argue that homosocial capital cannot be seen as a stand-alone factor, simply added to other forms of capital. We agree with this view. Bjarnegård (2013) contends that homosocial capital acts as an 
Table 5. Party office by gender (percentages)

\begin{tabular}{|l|c|c|c|}
\hline \multirow{2}{*}{} & \multicolumn{2}{|c|}{ Italian national party delegates 2004-2013 } \\
\cline { 2 - 4 } & Women & Men & $\Delta$ Women-men \\
\hline Current position in party & & & \\
\hline National, regional or provincial leader & 45.9 & 54.1 & \\
\hline Local leader & 16.7 & 19.3 & -8.2 \\
\hline No leadership position & 37.4 & 26.6 & 10.8 \\
\hline
\end{tabular}

informal interpersonal mechanism that has gendered consequences. Homosocial capital generates expressive resources, such as trust, likeability, predictability and familiarity. In particular, male homosocial capital is a Janus-faced concept. On one hand, it highlights the fact that interpersonal capital needs to be built up before an individual is included in a political network; on the other hand, it points to gendered interpersonal capital: it is predominantly accessible to men and more valuable when built up between men (Bjarnegård 2013).

Homosocial capital describes a propensity to consider background characteristics as a measure of predictability. It can be interpreted as an 'information short cut' in which candidates are evaluated on the basis of characteristics associated with their group (Krook 2010a). The unavoidable uncertainty in candidate selection may induce selectors to look for 'background characteristics as a proxy measure of abilities and character' (Norris and Lovenduski 1995, 14).

Yet operationalising the concept of homosocial capital is a challenging task, chiefly because it involves the measurement of expressive resources. Here we examine 'predictability' as a crucial element of homosocial capital. Predictability is a key feature of homosocial capital - it is the desire to cooperate with individuals whose behaviour and attitude can be understood and trusted (Bjarnegård 2013). One way of operationalising predictability is to inspect gender gaps in values. It is reasonable to assume that individuals with similar values form a subset, where behaviour is more predictable than for individuals who espouse different values. Similarity in values can thus be used as a proxy for homosocial capital. In the empirical analysis, we follow the political sociology literature that explores values by looking at post-materialist issues (Inglehart 1990; Inglehart and Welzen 2005; Norris 1999).

Table 6 reports similarities and differences between male and female party delegates in attitudes towards post-materialist issues (abortion, gay rights, environment). These figures reveal striking differences in the responses of male and female party delegates to questions regarding civil rights, such as abortion and gay rights. Women appear more progressive than men. They are less inclined to restrict abortion (the gender gap is more than 12 percentage points) and less likely to believe a foetus is an unborn citizen (13 percentage points less than men); women are more liberal with respect to drug use ( 7 percentage points gender difference) and more favourable to gay rights (about 20 points difference).

However, women's often more progressive attitudes can also be traced beyond the borders of political families. A recent paper on Italian party middle elites indicates that with regard to the ideological positions of parties, women delegates tend to be more post-materialist than men (Bordandini and Mulè 2018). Others find that increasing female descriptive representation in parliament affects the party policy agenda in a number of ways (Espírito-Santo, Freire and 
Table 6. Attitudes towards post-materialist issues. Differences between male and female delegates (\% agree)

\begin{tabular}{|c|c|c|c|c|c|c|}
\hline & $\begin{array}{c}\Delta \\
\text { Women-men }\end{array}$ & $\begin{array}{c}\Delta \\
\text { Women-men }\end{array}$ & $\begin{array}{c}\Delta \\
\text { Women-men }\end{array}$ & $\begin{array}{c}\Delta \\
\text { Women-men }\end{array}$ & $\begin{array}{c}\Delta \\
\text { Women-men }\end{array}$ & $\begin{array}{c}\Delta \\
\text { Women-men }\end{array}$ \\
\hline & All & Left & Centre left & Centre & Centre right & Right \\
\hline Getting an abortion should be made harder & -12.2 & 1.1 & -9.1 & -0.1 & -15 & -7.7 \\
\hline A foetus is a 'citizen' with same rights as mother & -13.2 & 1.6 & -10.7 & 12.6 & -7.8 & -3.5 \\
\hline Drug users should not be punished & 7.2 & -2.4 & 2.1 & 19.4 & -1.3 & -5.4 \\
\hline $\begin{array}{l}\text { Legislation should ensure equal rights for } \\
\text { homosexual couples }\end{array}$ & 19.6 & 1.9 & 18.7 & 5.8 & 0.6 & 2.5 \\
\hline $\begin{array}{l}\text { Environmental concerns should come before } \\
\quad \text { economics }\end{array}$ & 1.5 & -1.3 & -10 & -9 & -4 & 1.2 \\
\hline
\end{tabular}


Table 7. Attitudes to post-materialist issues (\% agree). Differences between male and female delegates by age (40 and under versus over 40 )

\begin{tabular}{|l|c|c|c|c|c|c|}
\hline & Women & Men & $\begin{array}{c}\Delta \\
\text { Women-men }\end{array}$ & Women & Men & $\begin{array}{c}\Delta \\
\text { Women-men }\end{array}$ \\
\cline { 2 - 7 } & $<=\mathbf{4 0}$ & $<=\mathbf{4 0}$ & $<=\mathbf{4 0}$ & $>\mathbf{4 0}$ & $>\mathbf{4 0}$ & $>\mathbf{4 0}$ \\
\hline $\begin{array}{c}\text { Getting an abortion should be made } \\
\text { harder }\end{array}$ & 13.1 & 22.4 & -9.3 & 16.1 & 28.1 & -12 \\
\hline $\begin{array}{c}\text { A foetus is a citizen' with same rights } \\
\text { as mother }\end{array}$ & 22.1 & 33 & -10.9 & 27.1 & 39.5 & -12.4 \\
\hline Drug users should not be punished & 63.5 & 62 & 1.5 & 64.2 & 54.4 & 9.8 \\
\hline $\begin{array}{c}\text { Legislation should ensure equal } \\
\text { rights for homosexual couples }\end{array}$ & 84.7 & 71.2 & 13.5 & 77.1 & 56.8 & 20.3 \\
\hline $\begin{array}{c}\text { Environmental concerns should come } \\
\text { before economics }\end{array}$ & 83.6 & 83.2 & 0.4 & 90.5 & 88.4 & 2.1 \\
\hline
\end{tabular}

Serra-Silver, 2020; Kittilson 2006, 2011; Greene and O'Brien 2016). It increases the diversity of issues in the election campaign and is associated with more left-leaning manifestos, even when parties' prior ideological positions are taken into account.

This gender gap in attitudes may adversely affect women's careers in political parties because it suggests that women are less predictable than men, if the expectation is a male norm. Candidate selection is not a 'hard science' but is strongly influenced by perceptions of trustworthiness, ability and qualifications. These perceptions are shaped by the preferences and opinions of party gatekeepers who are usually men. Scholarly work on gender political advancement indicates biases in the recruitment practices of political elites which lead to selection of fewer female candidates than males (Hinojosa 2012; Kenny 2013; Norris and Lovenduski 1995). These biases may be linked to a psychological desire to cooperate with individuals whose behaviour can be predicted and trusted, i.e. male homosocial capital.

Male homosocial capital can thus help to understand why Italian women delegates hold fewer executive positions, despite enjoying more cultural and social capital than men. Our results lend weight to comparative literature in the field, which indicates that parties are not gender neutral but based on a complex web of formal and informal norms and practices, the impact of which is different for women and men (Kittilson 2013; Lovenduski and Norris 1989; Norris and Lovenduski 1995; Waylen 2017).

Before concluding, it is worth exploring whether the gender gap in post-materialist attitudes is narrowing or broadening among younger Italian delegates. Table 7 shows the differences in attitudes to post-materialist issues between male and female delegates by age (40 years or under, over 40s). The data indicates that the gender gap narrows among younger delegates. For every item, the gender difference in attitudes towards post-materialist issues is systematically smaller. In some respects, these results are reassuring because they suggest that re-gendering party organisations may be possible in the not too distant future.

\section{Conclusion}

This article contributes to the literature on gender recruitment for party office in Italy by weaving Bourdieu's theory of personal capital with insights gained from advances in feminist institutional 
theory that address the role of informal institutional mechanisms. The latter suggest that what matters in recruitment patterns are informal encouragement and gatekeeping practices, 'leaving large room for leeway, interpretations and loopholes "on the ground"' (Bjarnegård and Kenny 2015, 380). Our work lends weight to this claim because it indicates that gender is pervasive in the recruitment process, shaping ways of valuing personal capital, so much so that women with more social and cultural capital than men hold fewer party office positions in Italy. Clearly, party gatekeepers value personal capital differently in women and men, suggesting that party office is a gendered political resource and gendered power dynamics are deeply entrenched in political parties.

The under-representation of women in the higher echelons of political parties raises questions of democratic justice, legitimacy, responsiveness and effectiveness. Since party delegates are involved in the approval of party programmes, the under-representation of women could substantially impact on policies, programmes and priorities of elected governments. This is a legitimate matter of democratic concern.

Like any research design, our study has limitations. It is a single-country study and focuses on party office holding, which could limit the generalisability of our results. Another limit of our dataset is that it does not allow us to explore a dynamic profile of party delegates because it is a snapshot of the delegates' situation. We are therefore cautious with our claims and do not attempt to end the debate on causality between party office, personal capital and informal mechanisms, using a gender perspective. However, we believe that suggesting a theoretical framework that employs 'varieties of capital', both personal and interpersonal, to shed light on gender political advancement, fosters progress in this area.

Our findings highlight the need for more and deeper research on gender political advancement, some of which depends on expanding data capacity beyond what is available today. One important avenue for future research is to tackle the complex measurement issues arising in the empirical analysis of homosocial capital, including identifying relevant indicators. Future research could also benefit from panel studies to inspect the dynamic profile of party delegates.

The varieties of capital approach can be applied in other contexts to further our understanding of gender patterns in the opportunity structure of political parties. It opens up promising research strategies in a growing body of work concerned with gender political advancement and with the quality of democratic representation.

\section{Acknowledgements}

We would like to thank the two anonymous reviewers of the journal for their constructive comments. This article is the product of a joint effort by the two authors, but the responsibility for the final draft is the following: PB: Unit of analysis, case selection and data; The gender distribution of personal capital; Conclusion. RM: Introduction; Theoretical framework: varieties of capital; Towards understanding party-office gender dynamics.

\section{Note on contributors}

Paola Bordandini is Associate Professor at the Department of Political and Social Sciences at the University of Bologna. Her work focuses on Political Culture and Political Parties Transformations. Her publications include La spada di Vendola (2013), I muscoli del partito (with Piero Ignazi, 2018), Cooperazione e cooperatori nell'Italia del risentimento (with Roberto Cartocci, 2020). At present, she is director of the research programme 'Italian National Party Delegates' at the Osservatorio sui Partiti Politici Aldo Di Virgilio at the University of Bologna. 
Rosa Mulè is Associate Professor at the Department of Political and Social Sciences at the University of Bologna. She is the author of several articles on political parties and party membership. Her publications include Dentro i DS (2007); Il Popolo di Rifondazione Comunista. Storia, opinioni e atteggiamenti degli iscritti al Prc (2009); and Il Mito Westminster. Giochi politici nei governi britannici (2012). She is currently working on a book entitled Gendering Varieties of Capital in Labour Market Policies.

\section{Notes}

1. Bourdieu's use of the term is distinct from that of others such as Coleman (1990) and Putnam (1993).

2. For detailed information regarding the history of the Italian national party delegate surveys see the website: https://centri.unibo.it/osservatorio-sui-partiti-aldo-di-virgilio/it/ricerca/la-storia.

3. Questionnaires were administered at the following national party conferences: Third PDCI (Party of Italian Communists) National Conference (Rimini, February 20-22, 2004); Second DL (Democracy is Freedom The Daisy) National Conference (Rimini, March 12-14, 2004); Third SDI (Italian Democratic Socialists) National Conference (Fiuggi, April 2-4, 2004); Second FI (Forward Italy) National Conference (Milan, May 27-29, 2004); Fourth MSFT (Movimento Sociale Fiamma Tricolore) National Conference (Fiuggi, December 11-12, 2004); Fourth NPSI (New Italian Socialist Party) National Conference (Rome, January 21- 23, 2005); Third DS (Democrats of the Left) National Conference (Rome, February 3-5, 2005); Second UDEUR (Union of Democrats for Europe) National Conference (Naples, February 18-20, 2005); Fourth PRC (Communist Refoundation Party) National Conference (Venice, March 3-6, 2005); First UDC (Union of the Centre) National Conference (Rome, July 1-3, 2005); National Assembly of the Greens (Fiuggi, November 10-12, 2006); Fourth DS National Conference (Florence, April 19-21, 2007); Third DL National Conference (Rome, April 20- 22, 2007); Seventh National Conference of the Italian Radicals (Chianciano Terme, October 30-November 2, 2008); First National Conference of The Right (Rome, November 7-9, 2008); Third AN (National Alliance) National Conference (Rome, March 21-22, 2009); PD (Democratic Party) National Assembly (Rome, November 7, 2009); First IDV (Italy of Values) National Conference (Rome, February 5-7, 2010); First SEL (Left Ecology Freedom) National Conference (Florence, October 22-24, 2010); First FDS (Federation of the Left) National Conference (Rome, November 20-21, 2010); and Third PD National Assembly (Milan, December 15, 2013).

4. Left-wing parties are the Partito Democratico (PD), Democratici di Sinistra (DS), Sinistra e Libertà (SEL), Partito dei Comunisti Italiani (PdCI), and Federazione di Sinistra (FdS).

5. National party delegates enjoy higher levels of education than the Italian population in general. Data from the Italian 2011 Census indicate that only $11 \%$ of the population has a higher education degree, of whom $7 \%$ are women and $4 \%$ men.

6. We use the simpler definition of Bourdieu's types of capital.

\section{References}

Achury, S., S. E. Scarrow, K. Kosiara-Pedersen and E. van Haute. 2020. 'The Consequences of Membership Incentives: Do Greater Political Benefits Attract Different Kinds of Members?' Party Politics, 26 (1), $56-68$.

Allen, P. and D. Cutts 2020. 'Personality and the Gender Gap in Political Ambition'. European Journal of Politics and Gender, 3 (1):11-32.

Baras, M., O. Barberà, A. Barrio, P. Correa and J. Rodríguez-Teruel. 2015. 'Party Membership in Spain and Congress Delegates'. In Party Members and Activists. An Overview, edited by E. van Haute and A. Gauja. London: Routledge.

Bardi, L., S. Bartolini and A. Trechsel. 2014. 'Party Adaptation and Organizational Change'. Party Politics. Special Issue 20 (2).

Bartolini, S., A. Chiaramonte and R. D'Alimonte. 2004. 'The Italian Party System between Parties and Coalitions'. West European Politics 27: 1-19.

Belluati, M., D. R. Piccio and R. Sampugnaro. 2020. 'Women's Access to the Political Sphere in Italy: When Obstacles Outdo Opportunities'. Contemporary Italian Politics, 12 (3): 278-86. 
Bjarnegård, E. 2013. Gender, Informal Institutions and Political Recruitment. Explaining Male Dominance in Parliamentary Representation. Basingstoke: Palgrave Macmillan.

Bjarnegård, E. and M. Kenny. 2015. 'Revealing the "Secret Garden": The Informal Dimensions of Political Recruitment'. Politics \& Gender 11 (4): 748-53.

Bjarnegård, E. and M. Kenny. 2017. 'Who, Where and How? Informal Institutions and the Third Generation of Research on Gendered Dynamics in Political Recruitment'. In Gender and Informal Institutions, edited by G. Waylen, 203-21. London: Rowman and Littlefield Internatioanl.

Bjarnegård, E. and P. Zetterberg. 2019. 'Political Parties, Formal Selection Criteria, and Gendered Parliamentary Representation'. Party Politics 25 (3): 325-35.

Bordandini, P. 2013. 'Renewal and Tradition: Comparing Italian Radical Left Parties through their Middle-Level Elites'. South European Society \& Politics 18 (1): 61-79.

Bordandini, P., A. Di Virgilio and R. Mulè, eds. 2011. 'I delegati congressuali di partito'. Polis. Special Issue 25 (2).

Bordandini, P. and R. Mulè. 2018. 'Attitudes and Opinions of Italian Middle-level Elites in the New Millennium. Adaptation, Innovation, or Persistence?' Italian Political Science Review 48 (1): 23-42.

Bourdieu, P. 1986. 'The Forms of Capital'. In Handbook of Theory and Research for the Sociology of Education, edited by J. G. Richardson, 241-58. New York: Greenwood.

Bourdieu, P. and J.C. Passeron. 1977. Reproduction in Education, Society and Culture. London-Thousand Oaks CA-New Delhi: Sage Publications.

Calise, M. 2010. Il Partito Personale. Bari: Laterza.

Celis, K., M. L. Krook and P. Meier. 2011. 'The Rise of Gender Quota Laws: Expanding the Spectrum of Determinants for Electoral Reform'. West European Politics 34 (3): 514-30.

Ceron, A. and Z. Greene. 2019. 'Verba volant, scripta manent? Intra-party Politics, Party Conferences, and Issue Salience in France'. Party Politics 25 (5) :701-11.

Cheng, C. and M. Tavits. 2011. 'Informal Influences in Selecting Female Political Candidates'. Political Research Quarterly 64 (2): 460-71.

Chiaramonte, A. and V. Emanuele. 2015. 'Party System Volatility, Regeneration and De-institutionalization in Western Europe (1945-2015)'. Party Politics 23 (4): 376-88.

Coleman, J.S. 1990. Foundations of Social Theory. Cambridge, MA: Belknap Press of Harvard University Press.

Cotta, M. and L. Verzichelli. 2000. 'Italy: From Constrained Coalitions to Alternating Governments?' In Coalition Governments in Western Europe, edited by W.C. Müller and K. Strom, 433-97. Oxford: Oxford University Press.

Dahlerup, D. and M. Leyenaar. 2013. Breaking Male Dominance in Old Democracies. Oxford: Oxford University Press.

Davis, A. 2010. 'Forms of Capital and Mobility in the Political Field: Applying Bourdieu's Conceptual Framework to UK Party Politics'. British Politics 5 (2): 202-23.

Di Virgilio, A. 2010. 'Cambiare Strategia a Regole Invariate. La Rivoluzione dell'Offerta'. In Proporzionale Se Vi Pare. Le Elezioni Politiche del 2005, edited by R. D'Alimonte and A. Chiaramonte, 33-74. Bologna: Il Mulino.

Espírito-Santo, A., A. Freire and S. Serra-Silva. 2020. 'Does Women's Descriptive Representation Matter for Policy Preferences? The Role of Political Parties'. Party Politics 26 (2): 227-37.

Evans, E. 2012. 'Selecting the "Right Sort": Patterns of Political Recruitment in British By-elections'. Parliamentary Affairs 1: 195-213.

Ewig, C. and F. M. Marx. 2013. 'Feminist Organizing: What's Old, What's New? History, Trends, and Issues'. In The Oxford Handbook on Gender and Politics, edited by G. Waylen, K. Celis, J. Kantola and S. L. Weldon, 411-35. Oxford: Oxford University Press.

Fox, R. L. and J. L. Lawless. 2011. 'Gendered Perceptions and Political Candidacies: A Central Barrier to Women's Equality in Electoral Politics'. American Journal of Political Science 55 (1): 59-73. 
Francheschet, S. 2017. 'Disentangling Informality and Informal Rules. Explaining Gender Inequality in Chile's Executive Branch'. In Gender and Informal Institutions, edited by G. Waylen, 115-35. London: Rowman and Littlefield International.

Gomez, R., L. Ramiro, L. Morales and J. Aja. 2019. 'Joining the Party: Incentives and Motivations of Members and Registered Sympathizers in Contemporary Multi-speed Membership Parties'. Party Politics doi.org/10.1177/1354068819891047.

Greene, Z. and D. Z. O’Brien. 2016. 'Diverse Parties, Diverse Agendas? The Parliamentary Party's Role in Platform Formation'. European Journal of Political Research 55 (3): 432-4.

Greene, Z. and M. Haber. 2016. 'Leadership Competition and Disagreement at Party National Congresses'. British Journal of Political Science, 46 (3): 611-32.

Guadagnini, A. 2005. 'Gendering the Debate on Political Representation in Italy: A Difficult Challenge'. In State Feminism and Political Representation, edited by J. Lovenduski, 130-52. Cambridge: Cambridge University Press.

Hinojosa, M. 2012. Selecting Women, Electing Women: Political Representation and Candidate Selection in Latin America. Philadelphia: Temple University Press.

Homsen, D. and A. King. 2020. 'Women's Representation and the Gendered Pipeline to Power'. American Political Science Review, 1-12. doi: 10.1017/S0003055420000404.

Hooghe, M. and A.-K. Kölln. 2020. 'Types of Party Affiliation and the Multi-speed Party: What Kind of Party Support is Functionally Equivalent to Party Membership?' Party Politics 26 (4): 355-65.

Huppatz, K. and S. Goodwin. 2013. 'Masculinised Jobs, Feminised Jobs and Men's "Gender Capital" Experiences: Understanding Occupational Segregation in Australia'. Australia Journal of Sociology 49 (2): 291-308.

Ignazi, P., L. Bardi and O. Massari. 2010. 'Party Organizational Change in Italy (1991-2006)'. Modern Italy 15 (2): 197-216.

Ignazi, P. and P. Bordandini. 2018. I muscoli del partito. Il ruolo dei quadri intermedi nella politica atrofizzata. Bologna: Il Mulino.

Inglehart, R. 1990. Culture Shift in Advanced Industrial Society. Princeton, NJ: Princeton University Press.

Inglehart, R. and C. Welzel. 2005. Modernization, Cultural Change, and Democracy: The Human Development Sequence. Cambridge: Cambridge University Press.

Josefson, C. 2020. 'How Candidate Selection Structures and Genders Political Ambition: Illustrations from Uruguay'. European Journal of Politics and Gender 3 (1): 61-78.

Kaltenegger, M., K. Heugl and W. C. Müller. 2019. 'Appeasement and Rewards: Explaining Patterns of Party Responsiveness Towards Activist Preferences'. Party Politics. doi.org/10.1177/1354068819854205

Karpowitz, C., Q. Monson and J. Preece. 2017. 'How to Elect More Women: Gender and Candidate Success in a Field Experiment'. American Journal of Political Science 61 (4): 927-43.

Kauppi, N. 2003. 'Bourdieu's Political Sociology and the Politics of European Integration'. Theory and Society 32 (5-6): 775-89.

Kenny, M. 2013. Gender and Political Recruitment. Theorizing Institutional Change. Basingstoke: Palgrave Macmillan.

Kittilson, M. C. 2006. Challenging Parties, Changing Parliaments: Women and Elected Office in Contemporary Western Europe. Columbus: Ohio State University Press.

Kittilson, M. C. 2011. 'Women, Parties and Platforms in Post-industrial Democracies'. Party Politics 17 (1): 66-92.

Kittilson, M. C. 2013. 'Political Parties'. In The Oxford Handbook on Gender and Politics, edited by G. Waylen, K. Celis, J. Kantola and S. L. Weldon, 536-54. Oxford: Oxford University Press.

Kölln, A.K. 2016. 'Party Membership in Europe: Testing Party-level Explanations of Decline.' Party Politics 22 (4): 465-77.

Kopecký, P. and P. Mair, eds. 2012. Party Patronage and Party Government in European Democracies. Oxford: Oxford University Press.

Krais, B. 2006. 'Gender, Sociological Theory and Bourdieu's Sociology of Practice'. Theory, Culture \& Society 23 (6): 119-34. 
Krook, M. L. 2010a. 'Why are Fewer Women than Men elected? Gender and the Dynamics of Candidate Selection'. Political Studies Review 8 (2): 155-68.

Krook, M. L. 2010b. 'Beyond Supply and Demand. A Feminist Institutionalist Theory of Candidate Selection'. Political Research Quarterly 63 (4): 707-20.

Lisi, M. 2015. 'Intra-party Democracy, Members and Middle-level Elites: The Case of the Portuguese Socialist Party'. Analise Social 50. 160-90.

Lovenduski, J. and P. Norris. 1989. 'Selecting Women Candidates: Obstacles to the Feminisation of the House of Commons'. European Journal of Political Research 17 (5): 533-62.

Lovenduski, J. and P. Norris, eds. 1993. Gender and Party Politics. London: Sage.

Lowndes, V. 1996. 'Varieties of New Institutionalism: A Reappraisal.' Public Administration 74 (2): 181-97.

Luhiste, M. 2015. 'Party Gatekeeper's Support for Viable Female Candidacy in PR-List Systems'. Politics and Gender 11 (1): 89-116.

Marche, J.C. and J.P. Olsen. 1989. Rediscovering Institutions. New York: Free Press.

McCall, L. 1992. 'Does Gender Fit? Bourdieu, Feminism, and Conceptions of Social Order'. Theory and Society 21 (6): 837-67.

McLeod, J. 2005. 'Feminists Rereading Bourdieu: Old Debates and New Questions About Gender Habitus and Gender Change'. Theory and Research in Education 3 (1): 11-30.

Morlino, L. 1991. Costruire la Democrazia. Gruppi e Partiti in Italia. Bologna: Il Mulino.

Müller-Rommel, F. and M. Vercesi. 2017. 'Prime Ministerial Careers in the European Union: Does Gender Make a Difference?' European Politics and Society 19 (2): 245-62.

Müller, W. 2000. 'Political Parties in Parliamentary Democracies: Making Delegation and Accountability Work'. European Journal of Political Research 31 (3): 309-33.

Niedermayer, O. 1986. 'Methodological and Practical Problems of Comparative Party Elites Research: the EPPMLE Project'. European Journal of Political Research 14 (1-2): 253-9.

Niven, D. 1998. 'Party Elites and Women Candidates: The Shape of Bias'. Women \& Politics 19 (2): 57-80.

Norris, P. 1999. Critical Citizens: Global Support for Democratic Government. New York: Oxford University Press.

Norris, P. and J. Lovenduski. 1995. Political Recruitment. Gender, Race and Class in British Parliament. Cambridge: Cambridge University Press.

O'Brien, D. Z. 2015. 'Rising to the Top: Gender, Political Performance, and Party Leadership in Parliamentary Democracies'. American Journal of Political Science 59 (4):1022-39.

O'Brien, D. Z., M. Mendez, J. Peterson and J. Shin. 2015. 'Letting Down the Ladder or Shutting the Door: Female Prime Ministers, Party Leaders, and Cabinet Ministers'. Politics \& Gender 11 (4): 689-717.

Palici di Suni, E. 2012. 'Gender Parity and Quotas in Italy: A Convoluted Reform Process'. West European Politics 35 (2): 380-94.

Pansardi, P. and M. Vercesi. 2017. 'Party Gate-Keeping and Women's Appointment to Parliamentary Committees: Evidence from the Italian Case'. Parliamentary Affairs 70: 62-83.

Papavero, L. C. and F. Zucchini. 2018. 'Gender and Party Cohesion in the Italian Parliament: A Spatial Analysis'. Italian Political Science Review 48: 243-64.

Pasquino, G. 2002. Il Sistema Politico Italiano. Autorità, Istituzioni, Società. Bologna: Bononia University Press.

Phillips, A. 1995. The Politics of Presence. Oxford: Clarendon Press.

Piscopo, J.M. and M. Kenny. 2020. 'Rethinking the Ambition Gap: Gender and Candidate Emergence in Comparative Perspective'. European Journal of Politics and Gender 3 (1): 3-10.

Power, S. and C. Dommett. 2020. 'From Multi-speed to Multi-stream? Recognising the Motivations, Processes and Triggers behind Party Membership'. British Journal of Politics and International Relations, 1+18. doi.org/10.11772F1369148120918852.

Putnam, R. D. 1993. Making Democracy Work: Civic Traditions in Modern Italy. Princeton, NJ: Princeton University Press.

Reddy, R., A. K. Sharma and M. Jha. 2019. 'Hegemonic Masculinity or Masculine Domination'. The International Journal of Sociology and Social Policy 39 (3): 296-310. 
Reif K., R. Cayrol and O. Niedermayer. 1980. 'National Political Parties' Middle-Level Elites and European Integration'. European Journal of Political Research 8 (1) : 91-112.

Rohrschneider, R. 1994. 'How Iron Is the Iron Law of Oligarchy? Robert Michels and National Party Delegates in Eleven West European Democracies'. European Journal of Political Research 25 (2): 207-38.

Sartori, L., D. Tuorto and R. Ghigi. 2017. 'The Social Roots of the Gender Gap in Political Participation: The Role of Situational and Cultural Constraints in Italy'. Social Politics 24 (3): 221-47.

Scarrow, S. 2015. Beyond Party Members: Changing Approaches to Partisan Mobilization. Oxford: Oxford University Press.

Siaroff, A. 2000. 'Women's Representation in Legislatures and Cabinets in Industrial Democracies'. International Political Science Review, 21 (2): 197-215.

Verge, T. and S. Claveria. 2017. 'Party Office, Male Homosocial Capital and Gendered Political Recruitment'. In Gender and Informal Institutions, edited by G. Waylen, 91-114. London: Rowman and Littlefield International.

Wacquant, L. 2004. 'Following Pierre Bourdieu into the Field'. Ethnography 5 (4): 387-414.

Waylen, G. 2017. Gender and Informal Institutions. London: Rowman and Littlefield International.

\section{Italian summary}

Questo articolo affronta il tema delle diverse possibilità di carriera politica delle donne all'interno dei principali partiti politici italiani tra il 2004 e il 2013. L'analisi si fonda su 5.122 interviste a delegati nazionali di partito realizzate durante 20 congressi nazionali. Le informazioni raccolte sono state elaborate attraverso un quadro teorico basato sui diversi tipi di capitale a disposizione dei quadri di partito intervistati. L'approccio proposto esamina le tre forme di capitale di Bourdieu - economico, sociale e culturale - e interpreta i risultati con strumenti analitici offerti dalla recente teoria istituzionalista femminista, in particolare il concetto di 'homosocial capital', sviluppato recentemente da Bjarnegård. I confronti tra donne e uomini in termini di background e traiettorie politiche rivelano la persistenza in Italia di indebite disparità nei percorsi di carriera delle delegate rispetto ai delegati che confermano ampiamente un modello di gerarchie di genere diffuso anche a livello internazionale. 